\title{
O JOVEM DO CAMPO: UMA FACETA DA(S) JUVENTUDE(S) CONTEMPORÂNEAS NO ESTADO DE GOIÁS
}

\section{YOUTH FIELD: ONE FACET OF THE(S) YOUTH(S) CONTEMPORARY IN THE STATE OF GOIÁS}

\author{
Priscylla Karoline de Menezes ${ }^{1}$ \\ ${ }^{1}$ Universidade Estadual de Goiás (UEG), Minaçu, GO, Brasil

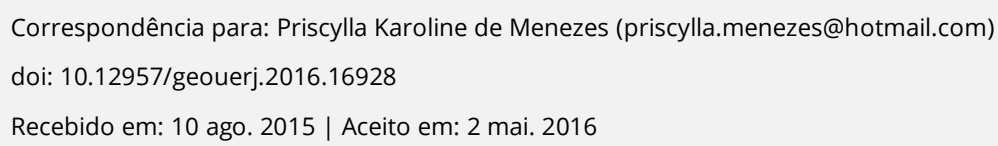

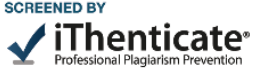

\section{RESUMO}

Esse artigo insere-se no conjunto de reflexões sobre o jovem do campo e suas práticas espaciais na contemporaneidade. $\mathrm{O}$ artigo teve como objetivo principal discutir como os jovens, que vivenciam o campo e a cidade cotidianamente, se espacializam por esses espaços e desenvolvem suas redes de sociabilidade. Na metodologia foram empregados procedimentos de estudos bibliográficos, a fim de identificar elementos que nos permitam refletir sobre o jovem do campo e pensar sua espacialização na cidade e no campo; e atividades campo, a fim de identificar jovens que atendiam a especialidade proposta para a análise. Apesar de trabalharmos, neste texto, apenas com dois exemplos, os resultados desta pesquisa nos permitem identificar alterações na forma das populações do campo olharem seus jovens; na postura dos jovens frente a sociedade; e uma espacialização pouco exploratória e ainda fundamentada nas redes de sociabilização próximas às residências e, ainda, tutoreada pelos pais.

Palavras-chave: Jovens do campo; Espacialização; Relação campo-cidade; Goiás.

\section{ABSTRACT}

This article is part of the set of reflections on the young from field and its spatial practices nowadays. The article aimed to discuss how young who experience the countryside and the city daily, if spatialize for these spaces and develop their social networks. In the methodology have bibliographic studies, procedures employed in order to identify elements that allow us to reflect on the youth field and its spatial thinking in the city and in the field. The results indicate changes in the way the people of the field look their young; in the attitude of young people across society; and a little exploratory spatial and still grounded in networks of sociability next to homes and also tutoreada by parents.

Keywords: Youth field; Spatialization; Relationshipfield-city; Goiás.

\section{INTRODUÇÃO}

Segundo o relatório da Organização das Nações Unidas (ONU) sobre a situação da população mundial, publicado em 2011, cerca de uma em cada duas pessoas vive em cidades, e em aproximadamente 35 anos duas entre três o farão (ONU, 2011). No Brasil, desde a década de 1970, quando foi diagnosticado estatisticamente que a maior parte da população passou a morar em cidades, estudos relacionados a esse movimento populacional foram intensificados. Debates a respeito foram se 
estruturando e os termos "rural" e "urbano" foram sendo incorporados com grande frequência às discussões acadêmicas e de gestão e planejamento territorial.

De acordo com Endlich (2010), discussões relacionadas ao rural e urbano foram muito difundidas no século XX, muitas com um olhar fortemente direcionado às limitações territoriais, que contribuíram para a adjetivação dos termos rural e urbano ligados ao campo e à cidade, respectivamente, e para o estabelecimento arbitrário de limites entre um e outro. Dessa forma, rural e urbano, na maioria das vezes, eram tratados como formas concretas e como parte dos espaços produzidos pela sociedade; esquecendo-se que estes ultrapassam essa relação de oposição entre campo e cidade.

Portanto, é necessário entender os papéis assumidos pelo campo e pela cidade e, consequentemente, suas complementaridades, as quais se materializam a partir das trocas simbólicas e econômicas que resultam em fluxos de informações e mercadorias. É preciso perceber que o campo e a cidade são espaços com uma grande parcela de pessoas morando em um e trabalhando, estudando, "vivendo" no outro, como é o caso de jovens que aqui apresentaremos, e de outros tantos espalhados pelo Brasil, que vivenciam o campo e a cidade cotidianamente. Indivíduos que vivenciam os espaços e, com base em suas experiências, constroem-se enquanto sujeitos sociais.

Desse modo, esse artigo visa discutir como os jovens, que vivenciam o campo e a cidade cotidianamente, se espacializam por esses espaços e desenvolvem suas redes de sociabilidade. Para a melhor obtenção desse objetivo, inicialmente foram realizados levantamentos bibliográficos e de pesquisas com temática correlata; atividades campo, afim de identificar jovens que atendiam a especialidade proposta para a análise e por fim apreciação dos dados coletados e elaboração do texto aqui proposto, que se apresenta dividido em três tópicos, os quais buscam estabelecer as relações entre campo e cidade na contemporaneidade - procuramos focar nas relações vividas no estado de Goiás, onde também foram realizados os campos desta pesquisa -, discutir o jovem nesse cenário e acompanhar como os sujeitos dessa pesquisa se espacializam.

Breves considerações sobre o rural e o urbano e a relação campo e cidade 
Para Lefebvre (1978), ao utilizarmos a concepção de rural e urbano, precisamos considerar que é o contexto socioespacial que diferencia esses espaços e não somente sua função. Ao abordá-los unicamente pelo aspecto do funcionalismo e reduzi-los à análise numérica, podemos mascarar elementos essenciais da vida urbana e/ou rural e, consequentemente, perdermos a noção de sua complexidade e seus processos na totalidade.

O rural e o urbano, então, não podem ser somente encarados como espaços ou propriedades empiricamente observadas, mas como resultado das relações sociais, que contemplam cultura, hábitos, economia e costumes. Em outras palavras, podemos ter o rural e o urbano em um lugar e não um lugar rural ou urbano. Saindo das interpretações que colocam esses espaços em contraposição, com características próprias e isoladas, somos capazes de ver o rural e o urbano em um contexto históricoespacial que vai além das interpretações puramente econômicas.

Sabemos que, com o processo de urbanização, o campo e a cidade sofreram significativas transformações que, de acordo com Spósito (2010), estavam ligadas principalmente ao acelerado crescimento do número de cidades e da quantidade de pessoas que passavam a viver nelas. Com novas lógicas sociais e de apropriação do espaço, campo e cidade foram assumindo novos hábitos, sociabilidades, ritmos e relações de trabalho que os diferenciavam e, ao mesmo tempo, os colocavam como complementares a partir das diferenças. Na visão da autora, era possível ver o cotidiano ser construído a partir de um tempo mecânico, seguindo a velocidade da mobilidade dos processos de produção, circulação, troca e consumo.

A terra, que era vista anteriormente como fonte de sobrevivência e que tinha relação direta com o trabalho, passava a ser vista mais como suporte para as diferentes atividades e edificações que viriam a se fixar nas cidades. Com seu conjunto de apropriações e combinações sempre dinâmicas, a cidade podia "ser lida como morfologia material, uma realidade presente, imediata, um dado prático-sensível, arquitetônico" (LEFEBVRE, 1991, p. 49). 
Com elevados índices demográficos e com suas diferentes lógicas econômicas e sociais, a cidade passou a ser associada à imagem do desenvolvimento, da modernização, do território das tecnologias e de infraestrutura básica, como água, luz, esgoto, hospitais, escolas, além da integração comercial. Imagem que surgia em contraposição aos hábitos, à cultura e à precariedade das condições de vida do sujeito no campo que, pela a ausência de políticas públicas voltadas ao fortalecimento do território camponês, principalmente no século XX, era fortemente influenciado pela supervalorização da vida na cidade.

Em Goiás, segundo Chaul e Silva (2004), as cidades geralmente tinham seu início a partir da construção de uma casa ou outra, ou de uma fazenda que, ao ceder terra para a construção de uma capela e uma praça, promovia novas povoações. Eram cidades que surgiam sob forte influência do modelo socioeconômico vigente na época. No início, eram as cidades formadas pela exploração do ouro, depois vieram cidades oriundas da atividade agropecuária e, em tempos mais recentes, surgiram as cidades planejadas, como é o caso de Brasília e Goiânia. Esse modelo de formação de cidades, segundo Suzuki (2007), não foi muito diferente em outras regiões do Brasil. Como o país sempre teve fortemente características agrárias, os arraiais, as vilas e as cidades apresentavam-se como formas de promover a ocupação do território nacional.

A população atraída pelo ambiente urbano, onde aconteciam as relações políticas, as concentrações demográficas e as articulações de valores culturais, passou a ocupar diferentes polos dinâmicos urbanos construídos por meio dos esforços oficiais no Brasil. A cidade de Goiânia, segundo Estevam (2004), é um exemplo dessas construções administrativas erguidas com uma de suas finalidades: promover novas formas de ocupação do território.

Edificada na década de 1930, para ser a nova capital do estado de Goiás, Goiânia lidou com diferentes fluxos migratórios que resultaram em significativas transformações em seu espaço urbano e no seu entorno. Portanto, em função da nova capital, novos municípios surgiram, os vizinhos se desdobraram (como é o caso de Anápolis e Trindade), houve a expansão das estradas, dos modelos de produção, transporte, infraestrutura e comunicação. Consequentemente, houve uma progressiva redução da população do campo. A redução da população no campo, nesse período, era um fato comum ao 
território nacional, que tinha o aumento significativo no número de pessoas que passavam a morar em áreas urbanas (ARRAIS, 2004). Para uma melhor visualização desse fluxo migratório, optamos por lançar os dados do Censo Demográfico no Figura 1, onde é possível acompanhar a taxa de urbanização no Brasil e no estado de Goiás desde a década de 1940 até 2010.

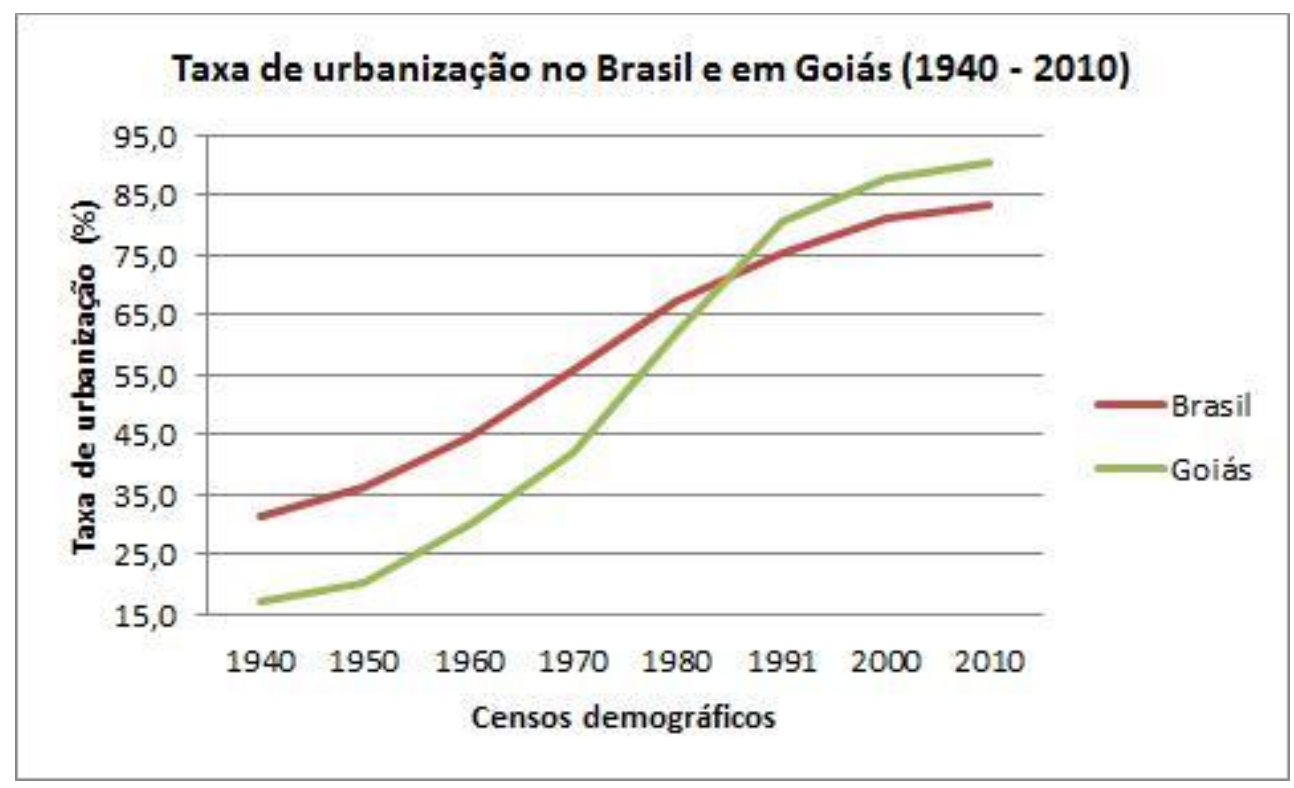

Figura 1. Taxa de urbanização no Brasil e em Goiás (1940 - 2010). Fonte: IBGE, Censo demográfico 1940-2010.

$\mathrm{Na}$ tentativa de quantificar a população brasileira quanto ao seu lugar de residência, o Censo demográfico, ao trabalhar com a taxa de urbanização, demonstrou também o alto fluxo migratório do campo para a cidade. Esse fluxo, conforme o Figura 1, veio se acentuando desde a década de 1940 até 2010, tanto em nível nacional quanto em nível estadual. No caso específico de Goiás que, segundo dados do Instituto Brasileiro de Geografia e Estatística (IBGE), apresentou no Censo 2010 uma população 90,20\% em área urbana - superior ao valor nacional 83,46\% -, acreditamos que o aumento na taxa de urbanização esteja relacionado à construção de Goiânia, à estruturação das cidades nos demais municípios do estado e à redução no número de postos de trabalho no campo.

A respeito das variações demográficas em Goiás, Chaveiro, Calaça e Rezende (2009) afirmam que essas variações estão relacionadas às funções desempenhadas pelos municípios e suas transformações territoriais. Para compreender as relações demográficas com as transformações territoriais do estado, os autores propõem olhar Goiás em dois períodos: de 1930 a 1970 e de 1970 a 2000. O primeiro 
período é visto como importante pelos autores, por se referir ao período das políticas expansionistas, momento em que acontecia a Marcha para o Oeste e, principalmente, era construída a nova capital do estado - Goiânia. Já o segundo período é visto como importante pelos autores, por se referir a "um outro Goiás", como assinalam Chaveiro, Calaça e Rezende (Ibid, p. 18). É nesse momento que se consolida uma infraestrutura no estado - energia elétrica, rodovias - a economia é modernizada e passa a se articular com a economia nacional e internacional, e ainda sofre influências da construção de Brasília. Desse modo, as modernizações ocorridas no espaço e no tempo resultaram na alteração dos modos de vida e dos seus arranjos espaciais, refletidos na atual distribuição populacional do estado que, como demonstrado na Figura 2, tem maior concentração em áreas urbanas que rurais.

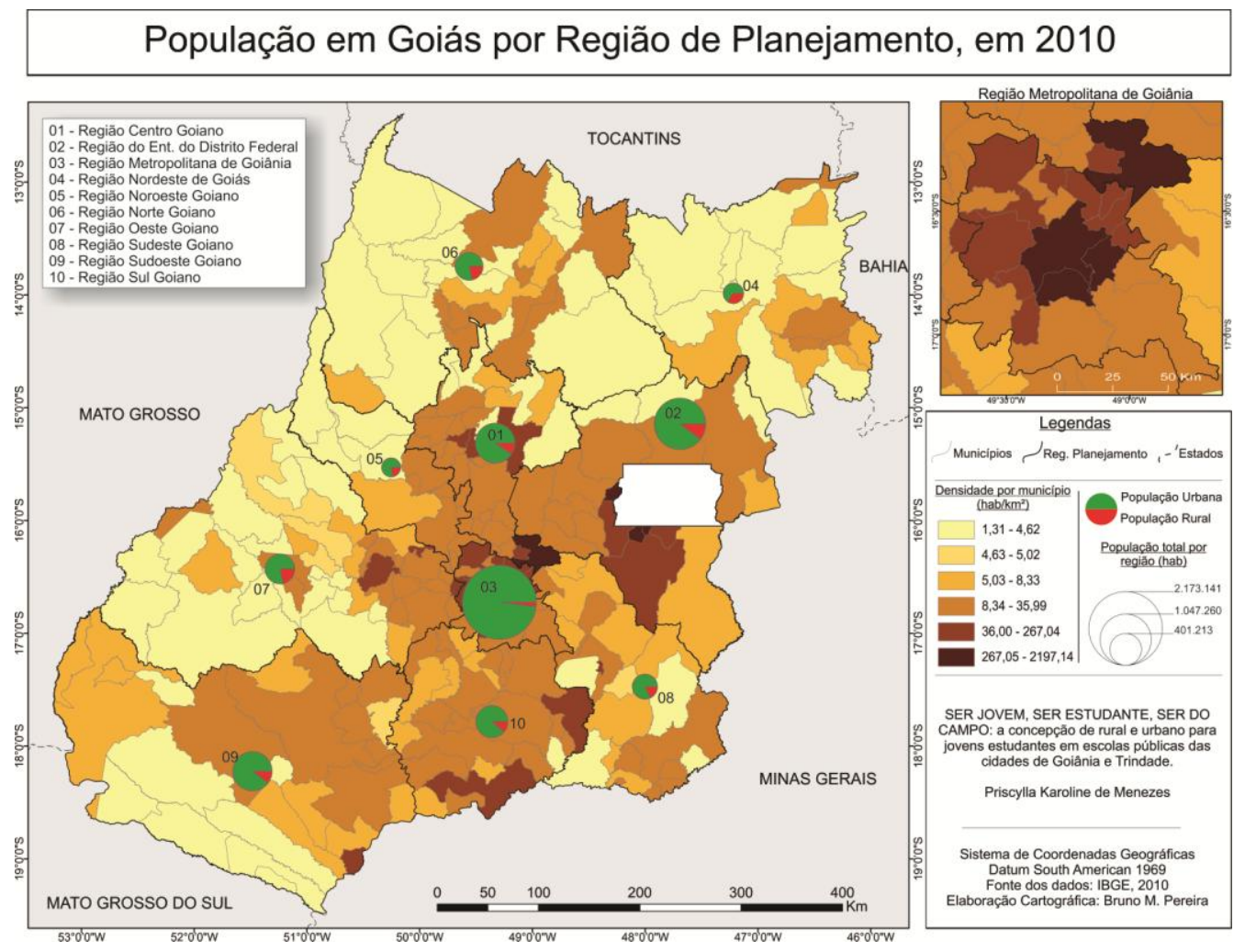

Figura 2. Taxa de urbanização no Brasil e em Goiás (1940 - 2010). Fonte: IBGE, Censo demográfico 1940-2010.

Com uma grande oferta de trabalho e bens de serviços nas cidades, e um acelerado processo de modernização agrícola em Goiás, houve uma concentração da população goiana em áreas urbanas a partir da década de 1970, distribuídas entre aglomerados, cidades, vilas e povoados - resultado de um espantoso crescimento da população urbana e redução dos residentes no campo. Influenciada pela industrialização do estado e, segundo Arrais (2004), pela não adequação ao novo modelo de produção, 
a população goiana proporcionou a partir da década de 1970 altas taxas de densidades demográficas. Isso ocorreu, de acordo com Censo 2010, principalmente, nas cidades próximas a Goiânia e a Brasília, que atingiram a marca de $98 \%$ de sua população residindo em área urbana.

Desse modo, no território goiano, loteamentos passavam a expulsar roças e matos, e a quebrar a ordem dos campos. Proprietários de terras, antes ocupadas por lavouras e pecuária, passaram a fragmentar suas terras e a transformar áreas rurais em urbanas, acumulando em seus espaços diferentes atividades econômicas e sociais.

Moysés (2005), ao estudar o processo de transformação de terras rurais em terras urbanas a partir do parcelamento da terra, constatou uma lucrativa valorização do metro quadrado, o que, segundo o autor, estimulava a ação entre os proprietários de terra. Ao trazermos os valores para uma análise na contemporaneidade, como propõe Moysés (2005), e usarmos o exemplo de Goiânia em tempos mais recentes - início da década de 2000 - vemos o alqueire goiano que era comercializado em torno de $\mathrm{R} \$$ 250.000 (duzentos e cinquenta mil reais) ser incorporado à área urbana e parcelado, e ter seu valor aumentado em até seis vezes.

Como resultado dos contínuos processos de expansão urbana, o campo e a cidade estreitaram significativamente as fronteiras entre seus territórios. Spósito (2010), ao discutir os processos que resultavam na aproximação entre cidade e campo, afirmou se tratar da alteração morfológica da cidade, que passou a ser "levada" para onde fosse conveniente e houvesse espaços produtivos. Assim, a partir dos loteamentos próximos ao campo, a cidade passou a se organizar em novas paisagens e a adequar suas práticas socioespaciais aos interesses políticos e econômicos do lugar, relacionando tempo e lógica capitalista. Desse modo, apesar de há muito tempo serem entendidos, pelos discursos acadêmicos, como complementares quanto aos seus fluxos de informações, mercadorias e capital, cidade e campo começaram a vivenciar suas populações em um mesmo contexto.

Como o campo e a cidade foram cada vez mais se aproximando e, conforme destaca Pessoa (2007), uma grande quantidade de pessoas passou a viver numa zona de intersecção entre o rural e o urbano 
das grandes e médias cidades. Os hábitos, culturas e comportamento cotidianos passaram a ser reorganizados de acordo com a nova realidade. Os espaços e suas funções assimilaram nova racionalidade técnica e variaram de acordo com suas regiões. Desse modo, a relação campo-cidade em Goiás se apresentou de diferentes formas, influenciada principalmente pelo modelo de modernização introduzido.

O espaço rural da Região Metropolitana de Goiânia, por exemplo, diferente de outras regiões do estado, tem a população camponesa vivendo principalmente nas pequenas propriedades, e mantém fortes ligações com a cidade, como afirmaram Chaveiro, Calaça e Rezende (2009) após um levantamento sócio econômico na região. Estando o rural em meio ao urbano, a tradição camponesa é inserida no contexto da cidade e exige novas interpretações. Com mais de um terço da população goiana, conforme Censo 2010, a Região Metropolitana de Goiânia atualmente não é uma região com elevados níveis de produção agropecuária, mas é interessante perceber que ainda apresenta municípios que se destacam na produção agrícola e têm na atividade significativa participação no Produto Interno Bruto (PIB) do município. Esse é o caso do alho em Nerópolis, do tomate em Goianápolis e do rebanho bovino de Trindade, além da avicultura em Goiânia, Nerópolis e Hidrolândia.

O PIB nos permite avaliar o fluxo da produção municipal segmentado pelos setores de atividades e, segundo os dados registrados pelo IBGEé possível observar a significativa participação da agricultura na economia de alguns municípios da Região Metropolitana de Goiânia. Caturaí e Caldazinha, com uma distância média de 30km de Goiânia, apresentaram, em 2010, índices que chegaram a mais 50\% do PIB ligado a atividades agrícolas; Nova Veneza, Brazabrantes e Santo Antônio de Goiás, localizados na porção Norte de Goiânia, apresentaram índices superiores a 30\% do PIB relacionado a atividades agrícolas; Hidrolândia, Guapó e Bela Vista de Goiás, localizados na porção Sul de Goiânia, apresentaram índices superiores a 10\% do PIB relacionado a atividades agrícolas; e Goiânia e Aparecida de Goiânia, municípios responsáveis por cerca de 26\% do PIB estadual, conforme informação da Secretaria de Estado, Gestão e Planejamento de Goiás (SEGPLAN), apresentaram índices que variavam entre $0,1-0,3 \%$ do PIB ligado a atividades agrícolas. Dessa forma, apesar das 
grandes influências da expansão urbana, alterações e concentrações de atividades tipicamente urbanas, tradições da vida rural permanecem no cotidiano da Região Metropolitana de Goiânia.

Lavouras temporárias e pastagens naturais destinadas à pecuária são paisagens comuns à Região Metropolitana de Goiânia. São espaços que têm sua existência ligada a atividades rurais e à permanência de uma ruralidade expressa nas práticas sociais. Oliveira (2011), ao estudar as ruralidades na metrópole Goiânia, vincula esse comportamento à metropolização de uma sociedade rural, que não construiu com um único tecido sua malha urbana. Portanto, essas novas relações entre campo e cidade vão se efetivando e passando a ser essenciais para a proposição de políticas adequadas, tanto para o espaço rural quanto para o urbano.

Nesse sentido, campo e cidade são materialidades que se concretizam como paisagens contrastantes, mas que podem atuar de maneira integrada. É possível à cidade sua organização em função da logística e demanda do campo, assim como também é possível ao campo sua organização a fim de atender a regulações da cidade. Esses espaços, segundo Graziano da Silva (2002), já não podem mais ser diferenciados por suas funções, ou separados por setores econômicos, uma vez que,

[...] o espaço rural não mais pode ser pensado apenas como lugar produtor de mercadorias agrárias e ofertador de mão de obra. Além de ele poder oferecer ar, água, turismo, lazer, bens de saúde, possibilitando a gestão multi-propósito do espaço rural, oferece a possibilidade de, no espaço local-regional, combinar postos de trabalho com pequenas e médias empresas (GRAZIANO DA SILVA, 2002, p. 28).

Portanto, é necessário entender os papéis assumidos pelo campo e pela cidade e, perceber que o campo e a cidade são espaços com uma grande parcela de pessoas morando em um e trabalhando, estudando, "vivendo" no outro. Indivíduos que vivenciam os espaços e, com base em suas experiências, constroemse enquanto sujeitos sociais. Como, grande parte desses sujeitos é jovem, que tem nessa prática fortes influências em sua construção social, cultural e histórica, torna-se evidente a necessidade de identificalo e analisa-lo em suas distintas posições ocupadas nos espaços socais a que se relaciona. 
Nesse sentido, é importante lembrar que as possibilidades de inserção social do jovem também estão condicionadas aos recursos materiais e simbólicos que lhe são disponibilizados. Com o ritmo acelerado das mudanças nas relações sociais e de trabalho no campo, que afetam também as noções de rural e urbano e deixam cada vez mais difícil a visualização das fronteiras entre cidade e campo - que vivem distintas realidades culturais e sociais, a juventude do campo torna-se cada vez mais complexa e passível de variedades de recortes analíticos e conceituais. Diante disso, vemos a necessidade de discutir o jovem contemporâneo que tem como cenário cotidiano o campo. No tópico a seguir, apresentaremos o jovem do campo na contemporaneidade.

\title{
O jovem na contemporaneidade e o campo como cenário
}

\begin{abstract}
Abordados por recentes estudos das diversas áreas de pesquisas da Ciência Humana - entre elas Sociologia, Educação, Antropologia e Geografia - o jovem veio sendo realçado quanto às suas mudanças de valores e comportamentos sociais nas últimas décadas. Indivíduos classificados segundo a faixa etária de 15 a 24 anos, pelos órgãos de pesquisa e legislação, nas últimas décadas passaram a ser considerados quanto a sua trajetória de vida e papéis sociais, o que lhes confere o direito ao “prolongamento" ou "encurtamento" de seu tempo de juventude, tempo que, segundo Novaes (2006), está claramente ligado à sua classe social.
\end{abstract}

Ao pensarmos o jovem do campo que, consoante Lei Federal nํำ 12.852/2013, passou a ter garantido em lei o direito à participação social e política, à educação de qualidade, à profissionalização, à comunicação, ao território e à mobilidade, fomos instigados a refletir sobre como podemos visualizá-lo em seu contexto espacial, e a nos questionar quanto à sua forma de vivenciar o campo e exercer sua condição juvenil frente às constantes alterações socioespaciais vivenciadas.

Sabe-se que tanto o campo quanto a cidade tem passado por significativas transformações em seus espaços e manifestações materiais, culturais, econômicas e sociais, que contribuem para a formação de espaços complexos e não mais exclusivos a determinadas funções e/ou atividades. Nesse sentido, o jovem tem chamado atenção de pesquisadores, como Carneiro (1998), que afirmam ser essa a faixa 
demográfica mais afetada pela dinâmica diluição das fronteiras entre campo e cidade. Pois são sujeitos que, em processo de formação da identidade, experimentam o confronto entre os laços que os prendem à cultura de origem - principalmente à família, e ao dinamismo trazido pela cultura urbana.

Nas palavras de Rizziniet al. (2009), a juventude é a parcela da sociedade mais afetada pelos problemas sociais, e limitada quanto a suas possibilidades de mobilidade e bem-estar social. Os jovens, segundo o relatório da Organização das Nações Unidas (ONU) sobre a situação da população mundial, publicado em 2011, representam 37\% da população mundial. No Brasil, os dados do Censo 2010 apontam que há mais de 35 milhões de jovens no país ${ }^{1}$, desses, $15 \%$ são jovens moradores do campo, ou seja, são 5.250.000 jovens que vivem o seu dia a dia no campo e que, muitas vezes, carregam uma juventude marcada por problemas quanto à sua formação profissional, discriminação de gênero, social, etária e espacial.

Situados em meio a uma cruzada entre a dependência e a autonomia social e econômica, os jovens do campo, de acordo com Castro et al. (2009), realçam os fortes embates quanto à sua posição hierárquica subalterna. Com o peso da autoridade paterna nas relações no campo, o jovem encontra, no espaço doméstico e em parte dos espaços sociais a que tem acesso, uma forte subordinação ao que entendemos por "vida adulta".

A relação de subordinação, trazida desde as gerações passadas, vai se configurando em constantes conflitos e frustrações entre gerações que, muitas vezes, resultam na rejeição da continuação da vida no campo e em uma negação ao mundo tal como estão inseridos. Esse comportamento de rejeição assumido pelos jovens, para Novaes (2007), é comum ao jovem e, muitas vezes, independe de estar no campo ou na cidade, pois "ser jovem é viver uma contraditória convivência entre a subordinação à família e à sociedade e, ao mesmo tempo, grandes expectativas de emancipação" (NOVAES, 2007, p. 7).

\footnotetext{
${ }^{1} \mathrm{O}$ valor apresentado é referente ao número de jovens com idades entre 15-24 anos, e não o valor absoluto apresentado pelo Censo 2010 de 51.330 .569 de jovens, que corresponde à população jovem entre 15-29 anos.
} 
O jovem que muitas vezes é considerado muito urbano pelos pais e roceiro por parte dos colegas da cidade, com quem estuda e/ou trabalha, segundo Castro et al. (2009), enfrenta fortes embates sociais em sua formação e na construção de sua identidade. Conflitos são intensificados se considerarmos as questões de gênero. Os autores, ao estudarem o peso da subalternidade relacionada ao gênero e às diversidades sexuais na vida dos jovens do campo, relataram uma subordinação ainda maior entre as jovens.

\footnotetext{
Se pudermos afirmar que ser jovem no espaço rural do Brasil carrega o peso de uma posição hierárquica subalterna, ser jovem e mulher e/ou ainda homossexual representa situação de subalternidade na hierarquia social ainda maior. [...] As jovens vivenciam intenso controle social, dentro e fora da família, exclusão dos processos de produção agropecuária, de sucessão e herança e, ainda, dos espaços de decisão. E, também, muitas vezes são as únicas responsáveis pelos afazeres domésticos de toda a família. O peso da autoridade paterna no espaço doméstico se estende para os espaços públicos de participação política. (CASTRO et al., 2009, p. 139).
}

Convivendo com o paradigma construído historicamente, que referenciava a mulher aos espaços privados, ao trabalho doméstico e à determinação do espaço social diferenciado do de homens, as jovens no meio rural há muito tempo vêm se organizando contra esse modelo social. Movimento que Castro et al. (2009) afirmam ter sido intensificado a partir da década de 1990, com o surgimento de movimentos sociais que militam sobre o tema. No entanto, como o controle social da mulher, sobretudo das filhas solteiras, está originado principalmente no interior da família e aparece na reprodução das relações patriarcais, esse comportamento ainda hoje não foi extinto.

Subordinadas inicialmente às regras e à vigilância do pai e, posteriormente, às regras do marido, as jovens do campo na atualidade têm percebido a oportunidade de sair de casa para estudar, como uma forma de se desvencilhar de tal processo. Apoiadas pela família a procurarem por melhores condições de emprego e de salário, por meio da continuação dos estudos, as jovens aparecem com maior destaque nos números referentes à migração temporária e/ou permanente de jovens do campo para a cidade (CASTRO et al., 2009). Sabemos que esse é um processo que não é comum a todas as jovens, pois depende de sua condição econômica e contexto familiar. Porém, é um aspecto importante que deve ser 
ressaltado, uma vez que é apontado por diferentes autores, entre eles Carneiro (1998) e Castro et al. (2009), como um dos responsáveis pelo processo de masculinização do campo. Segundo os dados do Censo 2010, já é possível perceber uma significativa diferença entre os jovens residentes de áreas rurais do Brasil, com um predomínio da população masculina - 53\% dos jovens entre 15 e 24 anos são do sexo masculino, contra $47 \%$ do sexo feminino.

Abramovay (2005), em seu levantamento sobre juventude rural e suas possíveis oportunidades no mundo contemporâneo, atesta que os rapazes são estimulados a permanecer no campo, e/ou a estudarem para dar continuidade às atividades agrícolas nesse novo contexto econômico. Contudo, são jovens que muitas vezes também discordam do modelo patriarcal assumido pela sociedade camponesa, e não fogem de confrontos, principalmente quando se discutem os modelos de produção, distribuição de funções e obrigatoriedade de sucessão.

O conflito entre gerações relacionado à subordinação e sucessão é um evento que Abramovayet al. (1998) identificaram ser comum desde a década de 1970, quando jovens primavam por inovações nas atividades agrícolas, enquanto os pais optavam pela tradição. Tal opção trazia ao cotidiano do jovem do campo o desejo pela busca de novos referenciais para a construção de sua identidade, fora da família. No entanto, o jovem do campo na contemporaneidade tem tido a possibilidade de continuar seus estudos e de estabelecer-se ou não nas atividades agrícolas, com suas perspectivas e relações familiares.

Desse modo, apesar de não ser comum a todos e de depender do contexto social e econômico em que está inserido, o jovem do campo, no que diz respeito às relações familiares, apesar de ainda ver centrado em seus pais o poder de decisão, de controle econômico e de produção, nos levantamentos de Abramovay (2005), parece ter adquirido, na atualidade, maior possibilidade de argumentação e discussão quanto à sua permanência ou não na propriedade. Acreditamos que essa atitude também pode estar relacionada à maior abertura dada pelos pais, que reconhecem os efeitos das transformações socioespaciais do campo e da cidade que incidem diretamente sobre a juventude. 
No que diz respeito à articulação social e política do jovem do campo, hoje é comum encontrar jovens que optaram por participar de movimentos sociais. Uns participam de movimentos de cunho religioso, como a Pastoral da Juventude Rural, outros de movimentos cuja fundamentação é política e social, como os movimentos sociais de luta pela terra. Esse comportamento é comum ao jovem brasileiro desde o início do século XX, conforme as abordagens recentes sobre a juventude, contudo não se estendia aos grupos que moravam no campo. Apesar de no campo também ter ocorrido alguns movimentos sociais nesse período, Castroet al. (2009) atestam que foi a partir da década de 1980 que esses movimentos passaram a olhar efetivamente para a condição dos jovens do campo e tê-los como participantes.

Castro et al. (2009) observam que alguns jovens do campo, incentivados pela família que tinha em seu histórico a participação em mobilizações sociais, e outros interessados na busca por melhores condições de vida e produção no seu lugar de vivência, no final da década de 1980 e início da década de 1990, deixaram sua posição de demanda local e passaram a assumir uma relevância no contexto nacional. Posicionamento que se reflete nos números oficiais disponibilizados pelos movimentos, mas que, de acordo com os autores, ainda não foi capaz de extinguir os conflitos intergeracionais e o distanciamento entre discurso e prática.

Rizziniet al. (2009) assinalam que os jovens do campo, como os jovens pobres da cidade, ao terminarem o ensino médio, tornam-se invisíveis às políticas públicas de assistência, assim como sua condição juvenil. Segundo os autores, ao terminarem seus estudos e não se verem contemplados pelas políticas públicas de desenvolvimento profissional e social, os jovens sentem-se invisíveis e perdidos nas encruzilhadas dos caminhos para a vida adulta. Invisibilidade que influencia diretamente na construção social do indivíduo que, muitas vezes, integra-se ao quadro de jovens com baixas expectativas profissionais e remunerações.

Com vivências juvenis afetadas por problemas, como a discriminação social e espacial que se diferenciam quanto ao pertencimento associativo (grupos religiosos, políticos, culturais), os jovens têm nesses demarcadores de identidades aproximações com jovens socialmente separados e o afastamento 
de outros jovens socialmente próximos e, assim, engajam-se à realidade que os circunda (NOVAES, 2007).

Ao considerarmos que os espaços, quando observados em uma perspectiva relacional, podem ter diferentes classificações, os atuais jovens do campo nos permite uma releitura de seu comportamento quanto aos espaços e a suas diferentes formas de idealizações. Releituras nos mostram a importância de se reconhecer que os jovens do campo atualmente são atores de uma reconstrução cultural, feita a partir de imagens construídas por eles, ao vivenciarem campo e cidade em seu cotidiano, e expressam uma nova mentalidade quanto às práticas e aos cenários. Sabemos que esse é um fato que não pode ser generalizado, contudo percebemos que o desejo de ruptura com o modo de vida rural nem sempre expressa o anseio pela saída do campo.

Assim, ser jovem na atualidade e ter como cenário a vida no campo e suas recentes transformações é diferente do que era ser jovem nas gerações passadas, pois os problemas e desafios encontrados são outros e a singularidade histórica pela qual estão passando ajuda a estruturar seus projetos de vida de maneira diferente do jovem urbano. Com singularidades em relação à família que, ao mesmo tempo, é unidade de produção e, por isso, deve ser levada em conta em seu projeto de vida, os jovens do campo se articulam para não perderem a comunicação com a família e com os amigos.

Nesse sentido, o comportamento assemelha-se ao encontrado no decorrer da pesquisa campo que aqui trazemos para a discussão. São jovens que, em sua maioria, visam continuar seus estudos e, assim, arrumar empregos com melhor remuneração na cidade, porém associam seu desenvolvimento à estabilidade que encontram nos lugares onde moram. Tais relações serão o foco das discussões do próximo tópico, no qual procuramos entender um pouco mais das práticas socioespaciais dos jovens moradores de Trindade, município localizado na região metropolitana de Goiânia.

\section{Ser jovem no campo e se espacializar na Região Metropolitana de Goiânia}


As jovens acompanhadas nessa pesquisa foram estudantes do Colégio Estadual Divino Pai Eterno, na cidade de Trindade, e moram em áreas rurais do município de Trindade, na Região Metropolitana de Goiânia. Contudo, apesar de serem semelhantes na idade, no gênero e tipo de moradia, é importante salientar que são jovens que apresentam atividades cotidianas particulares e diferentes perspectivas de análise do espaço e de vida - o que reforça a teoria da existência das distintas juventudes. Desse modo, achamos conveniente apresentá-las individualmente, segundo suas experiências cotidianas, preocupações futuras e trajetórias espaciais, para depois discutirmos como se apresentam nesse contexto.

Após finalizarem seus estudos no colégio referido, no ano seguinte, 2013, ano em que destinamos à pesquisa a fase de acompanhamento das atividades cotidianas das jovens, elas iniciaram novas atividades que influenciaram diretamente em suas práticas espaciais. Por isso, preocupamo-nos em acompanha-as em cada passo de atividades diárias, como: estudo, trabalho, festejos, entre outros. Desse modo, foram acompanhadas desde o momento em que caminhavam ao ponto de ônibus pela manhã até a chegada em suas casas, no final do dia; em reuniões familiares, passeios e/ou trabalhos em outras cidades, encontros com amigos e manifestações religiosas. Assim, segue-se um relato de atividades e reflexões realizadas com base no acompanhamento feito ao longo do primeiro semestre de 2013.

\section{Aluna 01}

Filha de pais migrantes, o pai mineiro de Araguari e a mãe tocantinense de Gurupi, a jovem nascida em Trindade no dia 20 de setembro de 1995 já morou em Anicuns e em Fazenda Nova. Hoje, mora na comunidade rural do Cedro, em Trindade. A jovem, desde pequena, viveu no campo e acompanhou as atividades diárias dos pais que até hoje trabalham com a terra. Filha mais velha de uma família composta por cinco pessoas, a Aluna 01, desde cedo, teve em casa algumas atividades a desempenhar, na maioria das vezes, atividades ligadas aos cuidados da casa, dos pequenos animais e de suas duas irmãs mais novas. 
Com relação aos estudos, a jovem iniciou o Ensino Fundamental em uma escola rural em Fazenda Nova e, com a mudança para Trindade, deu continuidade aos estudos na escola municipal localizada no Cedro, onde estudou até a quinta série. Terminado o Ensino Fundamental, a jovem, contando com o transporte escolar disponibilizado pela prefeitura de Trindade, passou a estudar na cidade de Trindade, a $22 \mathrm{~km}$ da comunidade onde mora. Como em Trindade há apenas duas escolas públicas que recebem estudantes vindos da Zona Rural do município, nessa etapa dos estudos, a Aluna 01 foi matriculada no Colégio Estadual Divino Pai Eterno, onde estudou até concluir o Ensino Médio e preparou-se para o processo seletivo do vestibular 2013/1.

A jovem, no decorrer do ano de 2013, dedicava-se diariamente às atividades escolares e às tarefas em casa. Em sala de aula, na escola, a Aluna 01 mostrava-se sempre participativa e preocupada com suas atividades e notas. Ao ser eleita representante da turma, a jovem passou também a se dedicar às tarefas que lhe eram passadas por professores e direção, a saber: auxiliar o professor, caso ele necessitasse sair da sala de aula, transmitir alguma informação da direção para os colegas de sala e também intervir em favor de sua turma nas reuniões com a direção.

Incentivada pelos pais a continuar os estudos e a procurar um emprego na cidade, onde pudesse obter melhores condições de trabalho e renda para ajudar a família, a Aluna 01, em 2013, começou a trabalhar nos períodos matutino e vespertino, como auxiliar administrativo em um escritório imobiliário, em regime CLT e, após a aprovação no processo seletivo para o curso de Gestão em Segurança Pública na UNI-Anhanguera, em Goiânia, iniciou seus estudos no período noturno. Atividades desempenhadas de segunda à sexta-feira.

A comunidade rural do Cedro não conta com linhas do transporte coletivo municipal, por isso a jovem todos os dias bem cedo, em companhia de seu pai e irmã, caminhava cerca de $1 \mathrm{~km}$ até a parada do ônibus escolar - responsável por levar os estudantes da zona rural à cidade de Trindade. Este também era utilizado por parte dos moradores da região, quando necessitavam ir à cidade. 0 sol ainda nascia quando a Aluna 01 tomava o primeiro ônibus do dia. As pessoas, a maioria jovens e crianças, ainda estavam silenciosas e comportavam-se de maneira meio sonolenta e, assim, se portavam durante quase 
todo o trajeto que durava cerca de 50 minutos até a entrada da cidade. Em meio à luz do sol que ia se firmando no horizonte, a Aluna 01 desembarcava próximo ao terminal de ônibus coletivo, onde tomava outro ônibus, com sentido ao centro histórico da cidade, local onde está a empresa em que trabalhava.

Ao final da tarde, após sua jornada de trabalho, a jovem retornava ao terminal rodoviário e tomava um ônibus, cedido pela prefeitura aos jovens de Trindade que são estudantes universitários em Goiânia. Três vezes na semana saltava próximo à Uni-Anhanguera, na região sudoeste de Goiânia, onde cursava Gestão em Segurança Pública e nos outros dois dias da semana saltava próximo à Avenida Goiás, no Centro de Goiânia, onde assistia a aulas em um curso preparatório para o concurso dos bombeiros. A aprovação no concurso estava diretamente ligada à sua expectativa de melhores condições no futuro, como demonstra sua fala.

Eu quero seguir carreira no serviço público, porque nele as condições de trabalho são melhores, a remuneração é fixa e, assim, tenho a possibilidade de ajudar minha familia. [...] Desde pequena eu e meu pai conversamos de um dia eu ser bombeira. Ele queria que fosse um de seus filhos, mas ele só teve filhas (Risos). Eu gosto da profissão, acho bonita e vejo na carreira militar um jeito de continuar estudando, enquanto ajudo as pessoas. Além do que, sempre fui boa com trabalhos pesados, em atividades físicas e sei bem como seguir regras. (risos) Espero me dar bem na carreira. [Aluna 01, Trindade, 2013].

Terminadas as aulas, a Aluna 01, em companhia dos colegas do ônibus, retornava à Trindade. Após a viagem de aproximadamente uma hora em um ônibus cheio de burburinho de vozes e algumas rizadas abafadas, a jovem saltava na entrada da cidade, onde reencontrava seu pai que ia buscá-la de moto e os dois se dirigiam novamente à comunidade rural do Cedro. Tal rotina era seguida pela jovem de segunda à sexta-feira.

Aos sábados, na parte da manhã, a Aluna 01 aproveitava para arrumar suas coisas e ajudar a mãe e as irmãs nas tarefas domésticas. Na parte da tarde, frequentava a casa de amigos e parentes, em 
especial dos avós, tios e primos, que moravam na comunidade ou na cidade de Trindade, e/ou ia à casa do namorado, que morava em Goiânia. É nesse momento que a jovem aproveitava para se relacionar com seus pares, ir à sorveteria com os primos e encontrar antigos colegas da escola. Em um clima descontraído, discutiam sobre suas atividades diárias e conversavam sobre seus cursos e fatos ocorridos no decorrer da semana. Quando ia a Goiânia, geralmente acompanhada de uma das irmãs ou dos pais, a jovem aproveitava para ir ao cinema e ao Shopping Portal, localizado próximo à Avenida Perimetral Norte, na região noroeste da capital, saída para Trindade, para namorar e andar pelas lojas.

De origem católica, a jovem e sua família aos domingos frequentavam a missa, na capela da própria comunidade do Cedro, capela que foi construída pela população que ali reside em devoção a São Sebastião. A jovem frequentava a igreja desde pequena e foi lá que realizou alguns dos sacramentos exigidos pela doutrina católica - batismo, catequese, crisma, entre outros. Participante do grupo de jovens da igreja, a Aluna 01 ajudava na organização de parte da cerimônia, enquanto conversava com outros colegas ali da região. Um domingo ao mês a jovem e sua família iam à missa em Trindade, em especial devoção ao Divino Pai Eterno, o qual ela afirmava ser o responsável por grandes milagres na família e na comunidade onde mora.

Em virtude de sua orientação religiosa e da tradição familiar, a Aluna 01, em conjunto com sua família e amigos da igreja, participava anualmente da festa em devoção ao Divino Pai Eterno, que acontece no final do mês de junho no município de Trindade. Para participarem do evento, eles iniciavam os preparativos meses antes, geralmente no final de março ou início de abril, quando começavam a organizar para o desfile o carro de boi, relíquia de família, e os mantimentos para o período de pouso. Esse comportamento é comum aos carreiros dessa festa, como demonstram Maia e Coelho (2006, p. 116), em relato dos estudos das tradições da roça na festa do Divino Pai Eterno.

Maio e junho é tempo já de preparar a romaria. Os ovos são guardados na areia para melhor conservação. Ajeita-se o sabão caseiro. Começa o preparo dos doces de figo, de laranja, de leite. E quitanda, muita quitanda: biscoito, bolos, broas e pãezinhos especiais. Mata-se o capado e prepara-se as latadas de carne para a viagem e o tempo da festa. Cada detalhe é importante. 
Cada gesto tem já um sentido de fé: o Pai Eterno espera para a bênção de todo ano. No finalzinho de junho, os carros de bois são preparados para a grande viagem. Acomodam-se as latas de alimentos, sacos de roupas, colchões e tamboretes, lonas e madeira para a barraca.

A casa da família todo ano era cedida aos carreiros que vinham de Anicuns e Nova Veneza, amigos da família que também desfilavam durante a festa, como forma de devoção e agradecimento ao Divino Pai Eterno. O período de pouso era marcado por rezas e festejos regados a muita música e comida - a maioria feita, ali, na hora, no fogão a lenha, alimentos produzidos e colhidos pelas famílias. Era comum ver os carreiros que ali acampavam se unirem para roçar o mato e colherem milho, mandioca e hortaliças. Ao anoitecer, os jovens se reuniam em volta das fogueiras para conversar e escutar histórias contadas pelas pessoas mais antigas do acampamento. Segundo a jovem, esse era um momento importante para eles, pois era uma forma de apreciar a beleza dessa tradição e de confirmar sua crença, como demonstrado em sua fala.

Os carreiros é a parte mais bonita da festa, é nessa hora que "a gente" vê a fé, o esforco e a vontade de agradecer ao Divino Pai Eterno por tudo que acontece na vida "da gente". É incrivel o tanto que isso é bom! [...] Eu quero participar dessa parte da festa o resto da minha vida e faço questão de continuar essa tradição. [Aluna 01, Trindade, 2013].

À exceção das festas oferecidas pela população da comunidade do Cedro que, muitas vezes, aconteciam à noite, e da participação na festa do Divino Pai Eterno, a jovem não tinha o hábito de sair à noite. Geralmente, frequentava festas diurnas oferecidas por parentes e amigos e não costumava ir desacompanhada de alguém da família, fato que a estudante associava à oportunidade de festejar com a família e aproveitar o lugar tranquilo onde moram. Para ela, "é bom sempre ir com a família, porque é um jeito 'da gente' se reunir e aproveitar o lugar sem marginalidade e onde as pessoas são amigas e livres para sair de casa sem se preocupar em ser abordada na rua”. [Aluna 01, Trindade, 2013]. 
Quando questionada quanto à sua concepção do campo e da cidade, a jovem que apresentava uma trajetória espacial construída a partir de caminhos que a levavam ao campo e à cidade, frisava que são espaços com diferentes usos, como evidenciado em sua fala.

São espaços que tenho bem claro para o que servem pra mim. A cidade pra mim é espaço onde tenho a oportunidade de estudar e trabalhar em serviços menos desgastantes e que me oferecem mais benefícios - melhor salário, plano de saúde e férias - mas também é o espaço onde eu tenho medo de andar sozinha e procuro não dar bobeira. Já o campo é o lugar onde me sinto bem, onde encontro minha familia e tenho a tranquilidade de andar e falar com as pessoas, além de poder ficar perto da natureza. Mas eu sei também que é um espaço com sérios problemas, ainda mais se a gente pensar no serviço e na assistência do governo; aqui se trabalha muito e poucas vezes somosreconhecidos por isso e, se precisar de um médico, vai morrer esperando. [Aluna 01, Trindade, 2013].

Desse modo, assim como os jovens apresentados por Guimarães e Silva Jr. (2012), a Aluna 01 frisa a ideia de lugares que se contrastam quanto às oportunidades, às formas de trabalho, aos serviços oferecidos e às relações estabelecidas. Tal imagem não é reforçada quando a jovem é perguntada sobre sua posição enquanto moradora do campo e estudante e trabalhadora da cidade.

Não vejo diferença, a gente que tá sempre na cidade, acaba que se comporta do mesmo jeito. As roupas são quase iguais, a forma de falar também [...]. É claro que tem coisas que eu não conheço ou não concordo, mas isso tem em todo lugar. [Aluna 01, Trindade, 2013].

Assim, apesar de ver diferença entre os espaços, a jovem diz não se sentir prejudicada quanto a suas relações ou a suas práticas espaciais. Pela trajetória que desenvolvia em seu dia a dia, que reforçamos no Mapa 3, a jovem que diariamente saia da comunidade rural onde mora e se deslocava para outras 
duas cidades para estudar e trabalhar, assim como os jovens trabalhadores que moram na cidade, aproveitava pouco os territórios juvenis da cidade.

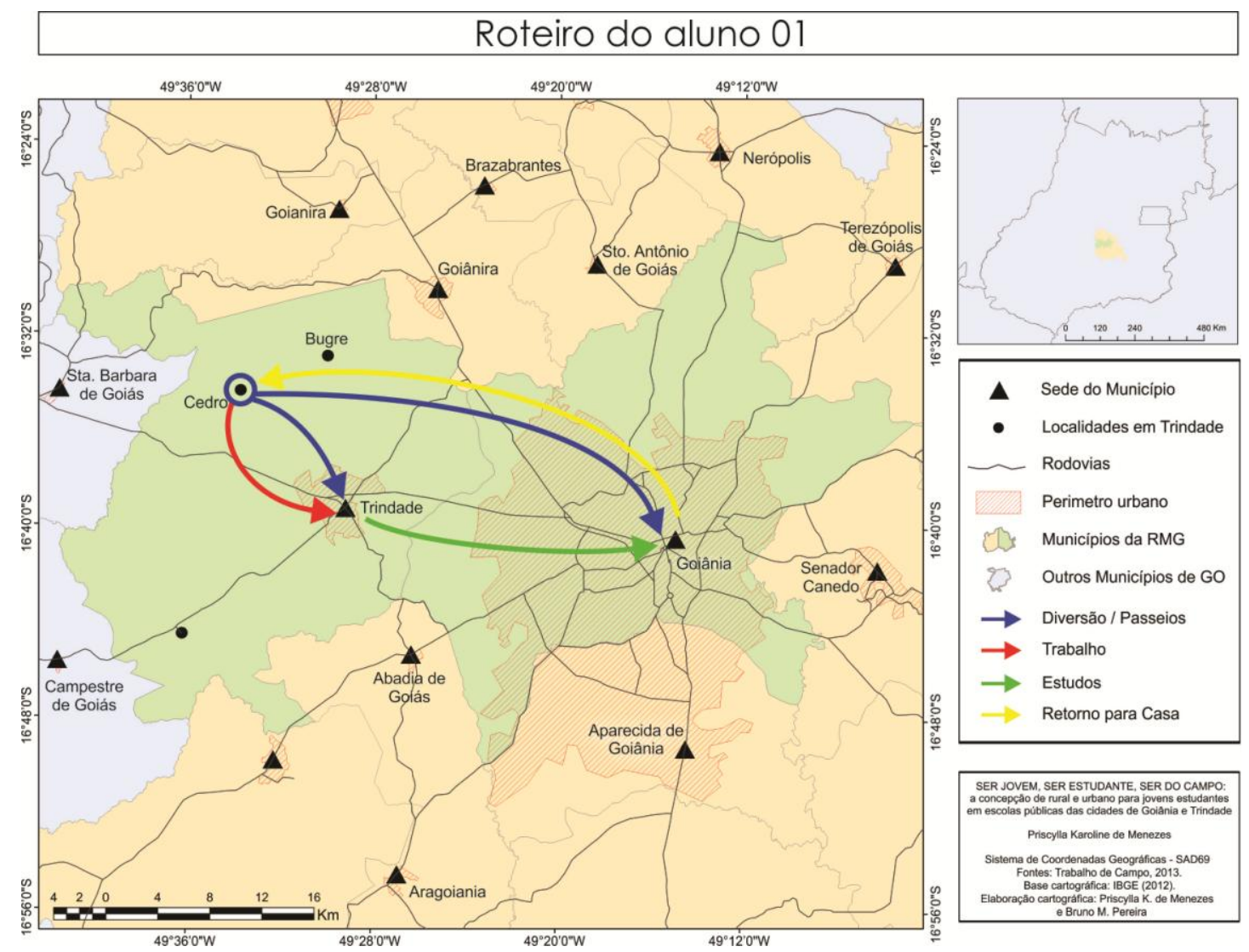

Figura 3. Roteiro do Aluno 01. Fonte: MENEZES P. K. Trabalho de campo, 2013.

Apesar de nos finais de semana procurar se relacionar com seus pares, a jovem se atinha aos espaços próximos de sua casa e de seus amigos. Influenciada também por sua classe social, a jovem não se apropriava de todos os espaços, mas sim daqueles que o cotidiano lhe ofereciam, e construía, assim, sua trajetória espacial a partir deles, seja no campo ou na cidade.

\section{Aluna 02}

Filha de pais paranaenses de Palotina que migraram para Goiás em busca de terra e serviço, a Aluna 02, nascida no dia 31 de março de 1996 em Novo Brasil, no estado de Goiás, hoje, reside na comunidade do Bugre, em Trindade, Região Metropolitana de Goiânia. Única filha entre três filhos, desde pequena, vive no campo e acompanha os pais em suas atividades diárias no trabalho com a terra 
e, em especial, no trabalho com o gado leiteiro. De acordo com a jovem, desde cedo aprendeu a ajudar nas tarefas de casa e a trabalhar com a produção de queijo, principal fonte de renda da família.

Com relação aos estudos, a jovem iniciou o Ensino Fundamental em uma escola rural na região, que oferecia até a quinta série, mas, pela falta de estrutura física da instituição e de profissionais responsáveis pela manutenção e pelo ensino, foi fechada antes que a Aluna 02 terminasse essa etapa de sua formação. Desse modo, a estudante precisou continuar seus estudos na cidade e passou a contar com o transporte escolar fornecido pela prefeitura de Trindade aos estudantes que moram na zona rural do município e precisam ir à cidade para estudar. Inicialmente, estudou na Escola Municipal Professora Gleide Mendes de Lima e depois foi transferida para o Colégio Estadual Divino Pai Eterno, onde concluiu o Ensino Médio e preparou-se para o processo seletivo do vestibular 2013/1.

Enquanto estudava no Colégio Estadual Divino Pai Eterno, no ano de 2012, a jovem se dedicava diariamente às atividades escolares e às tarefas em casa. Em sala de aula, a Aluna 02 era sempre comunicativa e, algumas vezes, dispersa ao assunto que era debatido pelo professor, pois era comum se distrair em conversas relacionadas às suas atividades do final de semana. Contudo, não se saia mal nas atividades de avaliação e na maioria das vezes era elogiada pelos professores por sua capacidade de reflexão.

Apesar do desejo de cursar Medicina Veterinária, a jovem, quando aprovada na seleção para o curso de Direito na Faculdade Aphonsiano, em Trindade, foi incentivada pela família a continuar seus estudos. O curso de Direito, segundo seus pais, é de grande importância social e para a família, pensamento que resulta do valor cultural dado ao curso na sociedade brasileira. Contemplada com meia bolsa na faculdade, a Aluna 02 começou a trabalhar como auxiliar administrativo na Prefeitura de Trindade na parte da manhã, de onde tirava sua renda para pagar a outra parte da mensalidade e custear suas despesas com os estudos. A jovem realizava seu curso no período noturno.

A comunidade rural do Bugre, por ser uma região formada principalmente por fazendas, não conta com linhas do transporte coletivo municipal, por isso a jovem todos os dias bem cedo era levada pelo pai até 
a parada do ônibus intermunicipal, onde o pai aproveitava para entregar o leite retirado no dia ao leiteiro da região. Ao raiar do sol, a jovem tomava o ônibus para Trindade, e cerca de 40 minutos depois, tempo gasto pelo ônibus para percorrer os $27 \mathrm{~km}$ de distância entre a comunidade rural e a cidade de Trindade, a jovem desembarcava próximo ao terminal de ônibus coletivo, onde se encontrava com o namorado que a acompanhava até o prédio da prefeitura.

Ao final da manhã, a jovem encerrava suas atividades na prefeitura e duas vezes na semana frequentava o curso de informática, oferecido pela secretaria de educação aos jovens estudantes que atuavam na instituição. Nos dias de curso, em companhia do namorado, almoçava e retornava à prefeitura para as aulas que duravam a tarde toda e, de lá, iam para a faculdade. Nos dias que não tinha o curso de informática, retornava à comunidade do Bugre, onde ajudava sua mãe com as atividades domésticas e na produção de queijo. A aluna 02 e a mãe eram as responsáveis por temperar, prensar, enformar e desenformar os queijos, que levados à feiras livres e supermercados de Trindade, por um dos irmãos da jovem.

Ao final da tarde, nos dias que voltava para casa, a jovem após o término de suas atividades preparava-se para ir à faculdade em Trindade. Acompanhada pelo irmão mais velho que cursava Gestão de Agronegócios, também na Faculdade Aphonsiano, a Aluna 02 ia à cidade de onde retornava tarde da noite, após o término das aulas. Nos dias em que as aulas terminavam mais cedo, a jovem aproveitava para ir com os colegas de curso à sanduicheria próxima à faculdade, lugar muito frequentado pelos jovens trindadenses que vão ali para lanchar e conversar com os amigos. Após lanche e conversa, a Aluna 02, acompanhada de seu irmão, retornava à comunidade do Bugre, onde encontrava o restante da família. Rotina que desenvolvia de segunda à quinta-feira.

Nas sextas à noite e aos sábados, a jovem, com o apoio dos pais e em companhia dos irmãos, amigos e namorado, participava de comitivas de divulgação de rodeios e desfiles de cavaleiros. Algumas vezes na cidade de Trindade, mas, na maioria das vezes, os jovens faziam o trabalho de divulgação em cidades próximas, como: Anicuns, Palmeiras de Goiás, Campestre, Guapó, São Luís dos Montes Belos e Goiânia. Quando não estavam em comitiva, eles costumavam se reunir pelas fazendas ou casas de 
amigos do grupo. A jovem, além de participar das reuniões com os amigos, aproveitava para sair com a família e visitar parentes em Trindade e em Palmeiras de Goiás.

Para a Aluna 02, participar das comitivas de divulgação era uma oportunidade de demonstrar a cultura que vive. Durante as observações, era possível entendermos que era uma atividade importante também para sua família, o que fica confirmado na fala da jovem.

Gosto muito de viajar para divulgar rodeios, desfile de cavaleiros e festas agropecuárias, porque desse jeito eu sinto que ajudo a valorizar o trabalho de gente como o pai e a mãe, a nossa cultura e o nosso jeito duro de viver. Tem gente que acha que não, mas eu entendo assim. Meu pai, quando era mais novo, também mexia com desfile de cavaleiros e conta pra gente que conheceu minha mãe numa dessas andancas. Ele fala tanto das experiências dele, que acho que é por isso que a gente gosta de cavalo e dessa cultura caipira, [...] é de tanto ouvir ele falar. [...] Até porque pelo dinheiro que a gente ganha nem dá pra animar muito, vai mesmo é pela alegria de "tá" com os amigos e montando um cavalo. (Risos). [Aluna 02, Trindade, 2013].

De origem católica, uma vez por mês ia à missa na Basílica de Trindade na companhia dos pais, em agradecimento ao Divino Pai Eterno e à Santíssima Trindade pelas bênçãos recebidas. De acordo com a família da jovem, é graças ao Divino Pai Eterno que eles conseguiram se estabilizar no município, mantendo-se com uma boa produção de leite e com a produtividade das terras da família. Nos domingos que não iam à Basílica, a jovem e sua família costumavam ir à missa que se realizava na capela da própria comunidade do Bugre. Essa capela, uma vez por mês, era cuidada pela família da Aluna 02 que, em devoção à Nossa Senhora do Perpétuo Socorro cuidava do espaço. Em conjunto com outras famílias da comunidade do Bugre, eles organizavam festas dedicadas à santa nos meses de maio, julho e outubro. Tais festas, devido à proximidade das comemorações juninas e da festa do Divino Pai Eterno, traziam à comunidade rural um grande número de pessoas. 
A jovem dizia que essas comemorações demonstravam o compromisso dos jovens moradores do Bugre com a comunidade e a expressão que o movimento religioso tinha em seu cotidiano. Ao falar sobre a festa de Nossa Senhora do Perpétuo Socorro e da Festa do Divino Pai Eterno, a jovem demonstrava novamente seu apreço pelos cavaleiros e confirmava que participar de tal grupo também lhe conferia uma sensação de ascendência durante as festas. Para os jovens, chegarem montados em seus cavalos era um ato de fé, mas também uma forma de se colocarem em evidência, como demonstra a fala da Aluna 02.

Participar da festa da Nossa Senhora do Perpétuo Socorro e principalmente da festa do Divino Pai Eterno é uma coisa que eu quero fazer pelo resto da minha vida! Nelas, eu sinto como se todo mundo lembrasse do valor das pessoas que moram no campo, da beleza e da força que tem as nossas rezas. Você viu! Não tem coisa mais bonita que quando "chega" os carros de boi e logo atrás os cavaleiros. Agora eles estão separando os grupos, porque os cavalos assustam um pouco os bois, que já ficam meio estressados mesmo com aquele tanto de gente. Mas quando é a hora "da gente" entrar no carreiródromo, todo mundo para. O grupo da frente solta os foguetes e "a gente" vem atrás devagar. Esse ano deve ter vindo uns 300 [cavaleiros], mas todo ano aumenta mais. Não sei te explicar a emoção que "a gente" sente quando o padre abencoa nossos cavalos e dá a benção um por um. É como se tudo até ali tivesse sido mais fácil. Meu pai e minha mãe ficam que não se aguentam de orgulho. [...] Mas, cá pra nós, uma coisa que eu acho engraçado é que tem gente que acha bobeira a gente ficar o ano todo envolvido com isso e fica falando 'não sei pra que isso', 'esse povo que mora na roça tem uns trem', mas lá na hora fica todo todo tirando foto pra por no facebook e chamando a gente de amigo. A gente sai de lá cheio de amigo! (Risos). [Aluna 02, Trindade, 2013].

É possível perceber que, para a jovem, esses desfiles estão ligados à religiosidade, mas também à sua expressão de lazer. Quando questionada quanto à sua concepção do campo e da cidade, a jovem que 
apresenta uma trajetória espacial construída por caminhos que a levam ao campo e à cidade, frisa principalmente a questão social e a proximidade dos espaços. Como inscreve em suas palavras:

Eu vejo o campo como um espaço onde as pessoas são simples, têm hábitos simples, trabalham muito pesado e nem sempre são ricos por isso. É um lugar onde tem tranquilidade e onde é possivel viver com naturalidade, fazer as coisas sem muita cerimônia, e fazer porque tem que fazer e não pra agradar ninguém. Já a cidade eu vejo com um espaço que é tumultuado e barulhento, onde o tempo parece que passa mais rápido, onde as pessoas também correm mais. Mas que eu também gosto, porque é na cidade que "a gente" encontra as coisas mais fácil, num dia só, você resolve um monte de coisa e ainda trabalha menos com o corpo. [...] Pra te falar a verdade, eu não vejo muita diferença entre os dois não, tá certo que a paisagem é diferente, a segurança é outra e a oportunidade de estudar e trabalhar melhor é mais fácil na cidade, mas tem muita coisa que tem nos dois. E, se eu posso morar em um e ir no outro pra procurar o que eu preciso, já tá bom. [Aluna 02, Trindade, 2013].

Assim como os jovens apresentados por Guimarães e Silva Jr. (2012), a Aluna 02 frisa a ideia de lugares que se contrastam quanto às oportunidades, dinâmicas sociais e formas de trabalho, mas são contrastes que, para a jovem, não dependem só do lugar, mas também do que procuramos. Desse modo, apesar de haver diferenças entre os espaços, ela parece não ver problemas em transitar entre eles, uma vez que não se sente prejudicada quanto às suas práticas espaciais. Pelo que foi apresentado pela jovem, apesar de algumas vezes ouvir alguns comentários sobre sua postura ou sobre o lugar onde mora, isso não afeta suas relações sociais. E, pela trajetória que desenvolve em seu dia a dia, demonstrada no Mapa 4, a Aluna 02, assim como os jovens trabalhadores que moram na cidade, apresentados pelos autores, aproveita pouco os territórios juvenis da cidade. Embora após a aula e nos finais de semana procure se relacionar com seus pares, a jovem se atém aos espaços próximos de sua casa e de seus amigos. 


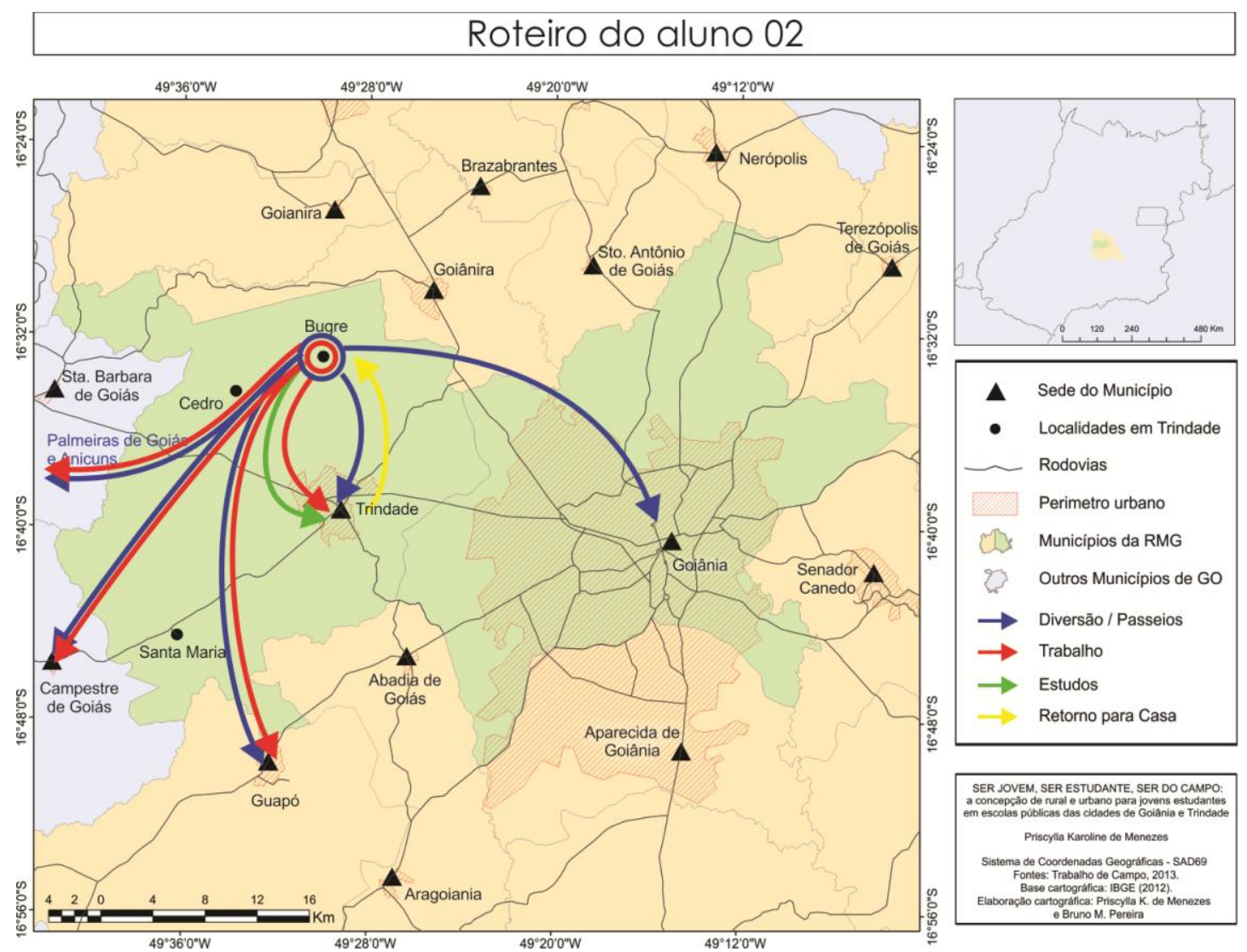

Figura 4. Roteiro do Aluno 02. Fonte: MENEZES P. K. Trabalho de campo, 2013.

A jovem não aproveitava a cidade como um todo, assim como não usufruía dos espaços que os jovens de maior poder aquisitivo utilizavam (como danceterias, bares jovens e outros espaços de estudos e lazer). Pelo que demonstrou em sua trajetória, a Aluna 02, utilizava-se dos espaços juvenis marginais ao centro da cidade e aos bairros mais "badalados" pela juventude. Segundo Martins e Souza (2007), esse é um comportamento que muitas vezes está submetido às condições materiais que também resultam nos gostos produzidos pelo universo sociocultural, gostos que não se restringe ao indivíduo. Ao observarmos o comportamento da jovem Aluna 02 podemos perceber, no atual contexto, as fronteiras entre o rural e o urbano diminuírem e cada vez mais se interpenetrarem. Entretanto, a possibilidade de lazer do jovem não se restringe devido ao espaço (campo ou cidade), mas sim devido à sua renda.

\section{CONSIDERAÇÕES FINAIS}


As jovens, segundo suas falas, não se sentiam oprimidas pelo fato de morarem no campo e constantemente estarem na cidade. São jovens que apesar de vivenciarem pontos semelhantes em seu dia a dia - como o fato de morarem em uma comunidade rural em Trindade, não terem transporte público para atender suas necessidades e trabalharem na cidade -, também experimentavam diferentes contextos em seu cotidiano, as vezes específico aos seus espaços de vivência. Singularidades que justificam a necessidade de compreender o jovem do campo enquanto indivíduo ativo, que em situações plurais fortificam e produzem aquilo que é expresso em suas linguagens, organizações e territorialidades.

Nesse sentido, apesar de termos apresentado apenas o exemplo de duas jovens, a partir desse estudo é possível percebermos que ser jovem na cidade, não é o mesmo que ser jovem no campo, assim como ser jovem na periferia não é o mesmo que ser jovem numa classe mais abastada. Contudo, as jovens entrevistadas revelaram a face de uma parcela da juventude que enfrenta dificuldades decorrentes de suas condições de vida e, também, o intenso processo de busca pela sobrevivência no espaço urbano. A situação vivida pelas jovens de Trindade - Região Metropolitana de Goiânia -, constitui um fator que define, em grande medida, um modo de vivenciar sua condição juvenil. São jovens que se mostram muito identificadas com os valores familiares e religiosos, traços característicos das populações do campo, pautadas pela obediência às regras impostas pela família e às devoções religiosas.

Sabemos que o jovem do campo, ainda é um sujeito difícil de ser discutido, tendo em vista sua complexidade sociocultural e sua pouca representatividade nas pesquisas no que concerne a suas dinâmicas culturais e sociais. Contudo, ao realizarmos esta pesquisa percebemos as desigualdades desse jovem da contemporaneidade. Apesar de os sujeitos terem em comum o fato de ser jovem e de morar em áreas rurais, são indivíduos que apresentam significativas disparidades, as quais muitas vezes estão relacionadas ao modo de ver e viver a vida, e de ter o direito ou não de exercer sua condição juvenil. Como acreditamos que as espacialidades e o lugar onde as pessoas vivem marcam profundamente suas identidades, essas diferenças e as maneiras de perceber e de se expressar nas diferentes situações cotidianas são marcas importantes demonstradas na forma de pensar dos jovens. 


\section{REFERÊNCIAS}

ABRAMOVAY, R. et al. Juventude e agricultura familiar: desafios dos novos padrões sucessórios. Brasília: Unesco, 1998.

ABRAMOVAY, R. Juventude rural: ampliando as oportunidades. In: Raízes da Terra: parcerias para a construção de capital social no campo. Secretaria de Reordenamento Agrário do Ministério do Desenvolvimento Agrário. Brasília - DF, Abril de 2005, Ano 1, n. 1. Disponível em: <http://www.creditofundiario.org.br /materiais/revista/artigos/artigo05.htm>. Acesso em: 08 out. 2012 .

ARRAIS, T. A. Geografia Contemporânea de Goiás. Goiânia: Editora Vieira, 2004.

BRASIL, Ministério da Educação. Censo escolar da Educação Básica 2012: relatório técnico. Brasília: Instituto nacional de Estudos e Pesquisas Educacionais Anísio Teixeira, 2013. Disponível em: < http://download.inep.gov.br/educacao_basica/ censo_escolar/resumos_tecnicos/resumo_tecnico_censo_educacao_basica_2012 .pdf>. Acesso: 25 jun. 2015.

CARNEIRO, M. J. O ideal urbano: campo e cidade no imaginário de jovens rurais. In: SILVA, F. C. T.; SANTOS, R.; COSTA, L. F. C. Mundo rural e política: ensaios interdisciplinares. Rio de Janeiro: Campus, 1998.

CASTRO, E. G. et al Os jovens estão indo embora?: juventude rural e a construção de um ator político. Rio de Janeiro: Mauad X; Seropédica; EDUR, 2009.

CHAUL, N. F.; SILVA, L. S. D. As cidades dos sonhos: desenvolvimento urbano em Goiás. Goiânia: Editora da UFG, 2004.

CHAVEIRO, E. F.; CALAÇA, M.; REZENDE, M. C. S. A dinâmica demográfica de Goiás. Goiânia: Ellos, 2009.

ENDLICH, A. M. Perspectivas sobre o urbano e o rural. In: SPOAITO, M. E. B.; WHITACKER, A. M. (Orgs.). Cidade e campo: relações e contradições entre urbano e rural. São Paulo: Expressão Popular, 2010.

ESTEVAM, L. A. 0 tempo de transformação: estrutura e dinâmica na formaçãoeconômica de Goiás. Goiânia: Ed. da UCG, 2004.

GRAZIANO DA SILVA, J. O novo rural brasileiro. 2. ed. Campinas: Unicamp, 2002.

GUIMARÃES, S.; SILVA JR., A. F. Ser jovem no Brasil: trajetórias juvenis no campo e na cidade. Campinas, SP: Alínea, 2012.

LEFEBVRE, H. De lo rural a lo urbano. Barcelona: Península, 1978.

0 direito à cidade. São Paulo: Moraes, 1991.

MAIA, C. E.; COELHO, T. O. Tradições da roça na festa do Divino Pai Eterno em Trindade (GO): comércio periódico e romaria de carros de bois. In: AGRÁRIA, São Paulo, № 3, 2006. p. 103- 122. Disponível em: <http://www.revistas.usp.br /agraria /article/view / 90/89>. Acesso em: 30 jun. 2015.

MARTINS, C. H.; SOUZA, P. L. A. Lazer e tempo livre dos(as) jovens brasileiros(as): escolaridade e gênero em perspectiva. In: ABRAMOVAY, M.; ANDRADE, E. R.; ESTEVES, L. C. G. Juventude: outros olhares sobre a diversidade. Brasília: Ministério da Educação Continuada, Alfabetização e diversidade, Unesco, 2007. 
MOYSÉS, A. Expansão urbana ou ocupação (in)sustentável da macro-zona rural do município de Goiânia. In: Observatório das Metrópoles. Ago. 2005. Disponível em: <http://www.observatoriodasmetropoles.ufrj.br/publicacoes/ary290805.pdf>. Acesso em: 27 set. 2012.

NOVAES, R. Juventude e sociedade: jogos de espelhos. Sociologia especial, ciência \& vida. Ano 1, n. 2, São Paulo: Editora Escala, 2007. p. 7-15.

Os jovens de hoje: contextos, diferenças e trajetórias. In: ALMEIDA, M. I. M. de; EUGENIO, F. (Orgs.). Culturas jovens: novos mapas do afeto. Rio de Janeiro: Jorge Zahar, 2006.

OLIVEIRA, U. F. "Marca d'água": o ser e o existir do rural no espaço metropolitano de Goiânia. 2011. Dissertação (Mestrado em Geografia). Instituto de Estudos Sócio-Ambientais. Universidade Federal de Goiás, 2011.

ONU - Organização das Nações Unidas. Relatório sobre a situação da população mundial 2011: pessoas e possibilidades em um mundo de 7 bilhões. Traduzida pelo Escritório do UNFPA no Brasil. UNFPA, 2011. Disponível em: <www.un.cv/files/PT-SWOP11-WEB.pdf>. Acesso em: 27 mai. 2013. p. 25-35, 1997

PESSOA, J. M. Extensões do rural e educação. In: (Org.). Educação e ruralidades. Goiânia: Editora UFG, 2007.

RIZZINI, I. et al. Percepções dos jovens sobre a influência dos adultos em seus processo de engajamento político-social. In: GUIMARÃES, M. T. C.; SOUSA, S. M. G. (Orgs.). Juventude e contemporaneidade: desafios e perspectivas. Brasília: Secretaria Especial dos Direitos Humanos; Goiânia: Editora UFG: Cânone Editorial, 2009.

SPÓSITO, M. E. B. A questão cidade-campo: perspectivas a partir da cidade. In: SPÓSITO, M. E. B.; WHITACKER, A. M. (Orgs.). Cidade e campo: relações e contradições entre urbano e rural. 2. ed. São Paulo: Expressão Popular, 2010.

SUZUKI, J. C. Campo e cidade no Brasil: transformações socioespaciais e dificuldades de conceituação. Revista Nera. Ano 10, n. 10. p. 134-150, janeiro/junho, 2007. Disponível em: <http://www2.fct.unesp.br/nera/revistas/10/suzuki.pdf>. Acesso em: 2 jul. 2015. 